KERLAN, Anne. 2018. Lin Zhao, « combattante de la liberté » (Lin Zhao: "Freedom fighter"). Paris:

Fayard.

Book reviews

\title{
Michel Bonnin
}

Translator. N. Jayaram

\section{OpenEdition}

\section{Journals}

Electronic version

URL: http://journals.openedition.org/chinaperspectives/9277

DOI: $10.4000 /$ chinaperspectives. 9277

ISSN: 1996-4617

\section{Publisher}

Centre d'étude français sur la Chine contemporaine

Printed version

Date of publication: 8 June 2019

Number of pages: $91-93$

ISSN: 2070-3449

Electronic reference

Michel Bonnin, « KERLAN, Anne. 2018. Lin Zhao, « combattante de la liberté » (Lin Zhao: “Freedom fighter"). Paris: Fayard. », China Perspectives [Online], 2019-2 | 2019, Online since 06 June 2019 connection on 19 December 2020. URL : http://journals.openedition.org/chinaperspectives/9277 ; DOI : https://doi.org/10.4000/chinaperspectives.9277

This text was automatically generated on 19 December 2020 .

(C) All rights reserved 


\section{KERLAN, Anne. 2018. Lin Zhao, " combattante de la liberté » (Lin Zhao: "Freedom fighter"). Paris: Fayard.}

Book reviews

\section{Michel Bonnin}

Translation : N. Jayaram

The name of Lin Zhao 林昭, the "freedom fighter" executed in Shanghai on 29 April 1968, was never expected to emerge from the oblivion to which the Chinese regime had consigned it. As the author notes, what normally awaited victims of Maoist movements was "silence, neglect, and destruction of proof: another form of violence" (p. 9). Fortunately, a spanner is sometimes thrown into the oblivion machine, as a result of which we are able to read this fascinating work.

2 This miraculous salvage unfolded in the following stages: the adoption of the "reform and opening" policy in early 1980s entailed the rehabilitation of a large number of victims of Mao era political campaigns, including Lin Zhao. Restitution to her sister of a major part of her prison writings, some written in her

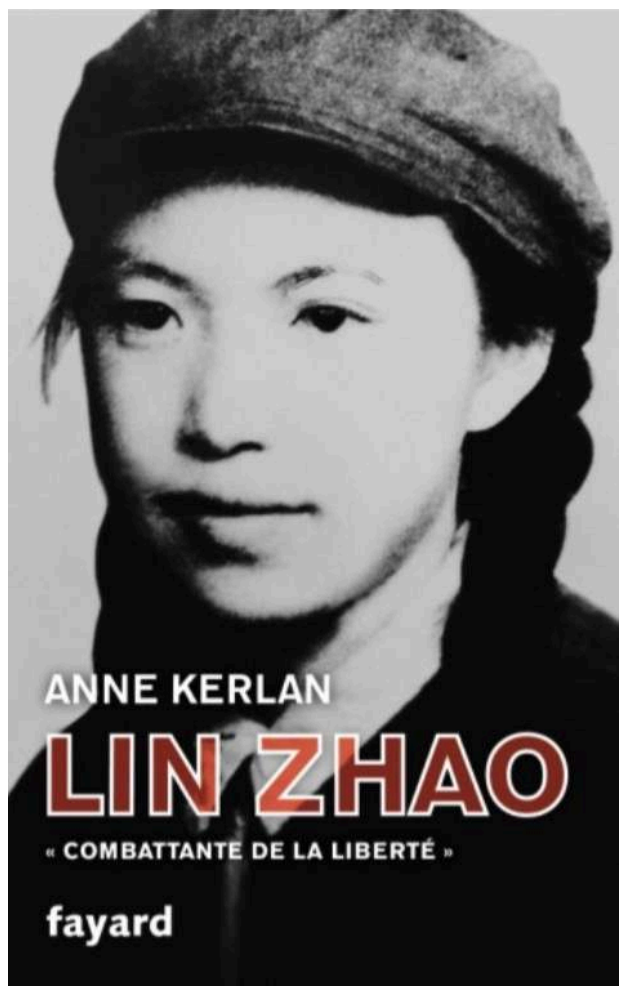
own blood on paper or cloth, was 
fortuitous, no doubt due to special sympathy on the part of an official who did not have to oblige. The texts denounced Mao and the Communist system with such virulence and accuracy that for a long time her sister dared not reveal their existence. Of course, Lin Zhao was not accorded full rehabilitation like that bestowed on Zhang Zhixin 張志新, another martyr who opposed Mao and the Cultural Revolution but in the name of Communist ideals.

3 It was much later, with the dawn of the new millennium and the popularity of digital cameras in China, that the main conservator of Lin Zhao's memory emerged. Hu Jie 胡 杰, a soldier turned artist and producer of independent documentaries, bravely ventured to make In Search of Lin Zhao's Soul (Xunzhao Lin Zhao de linghun 尋找林昭的靈 魂, 2004, 100 min.), which led him to seek out Lin's former friends and sister and through them the texts deciphered and assembled as a collection. Some friends wrote accounts that brought Lin alive. The film features them as well as Lin Zhao herself, with some passages of her writings read out by Hu Jie. The film served as a springboard for Lin Zhao's popularity and subsequent transformation to a sort of "dissident icon" (p. 13), as Anne Kerlan phrases it. It has been privately screened in many Chinese cities and in festivals abroad. The film prompted Anne Kerlan's work, and it was through $\mathrm{Hu}$ that she gained access to Lin's texts and to contacts useful for her research, which has been long and rigorous.

4 Kerlan has produced a classic historian's work in the positive sense, with a chronological progression, always placing her subject's individual experience in the historical context and seeking out similar cases in order to shed light on unclear matters. Thus Life and Death in Shanghai by Nien Cheng 鄭念, who was in the same prison as Lin, helps detail the grim conditions in which she passed the last days of her life.

5 From the viewpoint of form, the book is written in language that is elegant, pleasant to read, and vigorously expressive. It is all the more opportune that Lin was herself "literary" and wrote prolifically even in the worst conditions, not only political texts but also personal reflections and poems of quality. Kerlan presents large extracts from these texts, conveying the interest and pleasure evoked in reading them.

6 She rightly devotes ample space to introducing Lin's parents, who belonged to the 4 May 1919 generation, and to the experiences they had in their own youth. The two generations' trajectories help fathom the insoluble dilemmas each confronted and the incomprehension between them, deeply exacerbated by the attitude of the Party, which compelled young people to draw a line between themselves and their ostracised parents. Nevertheless, there is an evident resemblance between Lin and her mother, both idealistic, brave, and intelligent women. But that only comes through when Lin, imprisoned, understands how unfair she has been to her mother.

7 After the parents' experience, the focus turns to the young Lin Zhao, a good student specially gifted in literature who entered, as was done then, a good school in Suzhou run by American Protestant missionaries. She agreed to be baptised and to follow the catechism but was mainly drawn, as were many of her friends, by communism, which seemed to be the only effective alternative to the incompetent Nationalist government. She secretly joined the Party at the age of 16 in 1948, but was promptly identified, and the Party demanded her exit. She resisted and continued to take risks. Disobedient (and reckless), she was expelled from the Party but remained a member of the Communist Youth League. She never stopped trying to reintegrate. When the Communist army 
"liberated" Nanjing, a new problem arose: her family origins, with a father who held posts in the former administration and a mother who was member of a small democratic party tolerated by the CCP but considered "bourgeois."

Like many young intellectuals, Lin Zhao tried all means to fit the Communist mould, working ardently for the Party as journalist but also taking part in agricultural reform and in violence against "class enemies." Her future looked radiant when she won admission to Peking University's literature department and its journalism section, but like many intellectuals in all age groups, she faced the euphoria of the Hundred Flowers Movement, which brusquely transformed into the nightmarish Anti-Rightist Campaign. Punished rather lightly, Lin could have quickly resumed her normal routine, but she was unable to desist in supporting her harshly condemned friends and lost faith in the regime. After trying to commit suicide, she ended up taking a certain pride in her "rightist" status. During "supervised work," she did not shirk from attending mass regularly. She had friends, at least one of whom was her lover. They tried to get married but rightists had no such right... Learning of the terrible famine following the Great Leap Forward, she took part in a clandestine publication of some rightist intellectuals called Spark (Xinghuo 星火), which openly denounced the regime despite the reigning terror. Having lost all respect for the Communist authorities, Lin and her companions deemed it their duty to resist and were ready to pay the price. Writing later, Lin expressed her generation's grief: "Our innocence and integrity were used; our goodness, pureness of soul, enthusiastic and warm temperament were all used insidiously. And when we were more mature and began to learn of the absurd and cruel reality, when we began demanding the democratic rights due to us, we were persecuted, tortured, and oppressed in the cruellest manner (p. 250)." Jailed for a year, she was freed for medical reasons, but rather than taking it easy and trying to go unnoticed as others did, she openly expressed revolt.

Lin Zhao returned to jail in Shanghai in November 1962, never to leave. Mao's preparations for the Cultural Revolution and its launch only aggravated the repression to which she fell victim. She faced inhuman conditions of cold, hunger, beatings, sexual abuse, and other forms of torture. During her numerous hunger strikes, she was forcefed through a tube inserted in her nose, which made her bleed. She was kept shackled for months on end, making all daily movement difficult and painful as metal penetrated the skin. But nothing held Lin back from her personal struggle against tyranny. She was initially sentenced to 20 years' imprisonment in 1965, then condemned to death and executed in Tilanqiao 提籃橋 jail on 29 April 1968. The death penalty was no doubt because of her refusal to admit her "crimes" and her regular sacrilegious denunciations of Mao and his cult in her writings. On 1 May, a policeman informed her mother, who had had no news for six months as the prison held back letters, that her daughter had been executed, and in line with the practice then, he also demanded 5 cents as payment for the bullet used to kill her daughter.

10 Under Mao, repression against an individual for political reasons affected the whole family. Her father had committed suicide before his daughter's death, and the mother later made an unsuccessful attempt but died miserably in 1975, after suffering frequent beatings from her son, who was mentally deranged thanks to the prevailing situation. Only Lin's sister, surviving years of terror, managed to transmit Lin Zhao's memory, to write some of her own recollections, and, persuaded by $\mathrm{Hu}$, revealed the astonishing prison writings. 
11 Entitled "Ink and blood: Lin Zhao's struggle," the entire chapter on her five-and-a-half years in Tilanqiao is a model of precise analysis and subtle sympathy with the subject. In the sinister and sordid prison surroundings, with her body martyred and humiliated, Lin drew strength from writing, one rooted in her own body, often using her own blood in place of ink.

12 Lin Zhao is now often reduced to the figure of a Christian martyr. Anne Kerlan, on the contrary, has demonstrated the complexity of her person and the multiple moral resources that underpinned her exceptional ability to resist Maoist totalitarianism. What the West offered Chinese intellectuals in the twentieth century was not just Christian faith, which only touched a part of them, but more generally a humanism with universal vocation, inherited from the Enlightenment and the French Revolution, based on the notions of liberty, equality, and democracy. Lin Zhao clearly stood for both traditions, and while she often invoked divinity, she also wrote to the UN General Assembly, asking it to take interest in the Chinese people's human rights. She had faith in humanity and history, declaring from the depths of prison, where her voice was not expected to ever be heard, that history would vindicate her. Anne Kerlan rightly cites another essential source of Lin's power of resistance: her passion for writing and faith in the power of writing. So long as she could write, including by dipping into her own blood, she felt she existed beyond herself.

What is particularly interesting, and which the book brings out, is both the young woman's representative character (through her, we grasp the intellectuals' desire to serve New China and to be rid of the stigma of their bourgeois origins, their shock over the miseries wrought by the Anti-Rightist Movement, and their disappointment with the regime) and her exceptional personality: her heroic rejection of any compromise right until the end, which evokes affection and admiration.

In conclusion, the annexes, containing a chronological list of all of Lin Zhao's documented texts and biographical notes of the main people cited, are most useful. The author's only historical error is a minor one: Bian Zhongyun, the first school principal beaten to death by her students, and subject of another acclaimed $\mathrm{Hu}$ documentary, died on 5 August 1966, not 5 June.

The book's editing is less than perfect, with typos in places and missing references in the bibliography, but above all in the archaic method of placing notes, forcing the reader to constantly jump to the end of the book for texts cited. These minor defects take little away from the strengths of the book, which ought to interest both specialists and the general public, who will discover a major figure of a free woman whose struggle is unfortunately also current reality. Anne Kerlan brings out how this young, sentimental Chinese person, beautiful and elegant, who grew up in one of china's loveliest cities and became a talented student in the country's best university, an imbiber of classical culture and representing refinement and gentleness, and the daughter of a modern and Westernised couple, was not meant to engage in such a violent struggle. Lin Zhao herself raised the question: "Even in a land containing antique relics such as China, is it not possible to have a civilised political dispute without bloodshed?" (p. 252).

Alas, it was totally impossible in Mao's China, and the death in prison of Nobel Peace Prize winner Liu Xiaobo in 2017 shows it is still so now. Anne Kerlan concludes: "The struggle continues" (p. 298). 


\section{AUTHORS}

\section{MICHEL BONNIN}

Michel Bonnin, Director of Studies, School of Advanced Studies in the Social Sciences (EHESS).

michel.bonnin@gmail.com 